\title{
Corporate governance, ownership structure and voluntary disclosure: Evidence from listed firms in Malaysia
}

\author{
POH-LING HO \\ Senior Lecturer, School of Business \\ Curtin University \\ CDT 250, 98009 Miri, Sarawak, Malaysia \\ Phone: +60 85443939 \\ pauline.ho@curtin.edu.my
}

\author{
GRANTLEY TAYLOR \\ Senior Lecturer, School of Accounting \\ Curtin Business School, Curtin University, GPO Box U1987 \\ Perth, Western Australia 6845 \\ Phone: +61 892663377 \\ Grantley.Taylor@cbs.curtin.edu.au
}

\section{Brief professional biography:}

Poh-Ling $\mathbf{H o}$ is the senior lecturer in School of Business at Curtin University, Sarawak Malaysia. She is a CPA and a Chartered Accountant (Malaysia). She holds Bachelor and Master degrees in Accounting from Australia. She obtained her Doctorate degree in 2010. Her research specializations include corporate governance, corporate disclosure and earnings management. Her previous publications have appeared in journals such as Corporate Ownership and Control and International Journal of Managerial and Financial Accounting.

Grantley Taylor is a lecturer in financial accounting in the School of Accounting, Curtin University. He completed a research doctorate. He has successfully supervised several Doctoral and Honours students. Recent publications have appeared in journals such as Accounting and Finance and Asian Review of Accounting.

Acknowledgement: We appreciate the comments from conference participants at the 2010 AFAANZ Conference, 4-6 July, Christchurch, New Zealand. The authors gratefully acknowledge Professor Greg Tower for his guidance and helpful comments. 


\begin{abstract}
This paper examines the impact of corporate governance and ownership structure on voluntary disclosure practices of Malaysian listed firms. The extent of voluntary disclosure is determined for a matched-sample of 100 listed firms in three different disclosure regimes during 1996, 2001 and 2006. The findings suggest that regulatory reforms over the 1996-2006 period resulted in enhanced corporate transparency and accountability as reflected in more extensive voluntary disclosures. We provide empirical evidence that the extent of voluntary disclosures is significantly associated with the strength of corporate governance structure in 2001 and 2006 and with ownership structure in 1996, 2001 and 1996. . The findings of this study are of use to regulators in terms of guiding policy development regarding corporate transparency of publicly listed firms.
\end{abstract}

Key words: Voluntary disclosure; corporate governance, ownership structure, disclosure-based regime, ownership concentration, agency theory, Malaysian Code of Corporate Governance, corporate transparency and accountability, corporate communication, Malaysia 


\subsection{Introduction}

The regulatory constraints of stock exchanges play an important role in the economic development of emerging or developing economies. Over the past decade, the Bursa Malaysia Stock Exchange (BMSE) has become an increasingly important avenue for listed firms to access capital. Disclosure of corporate information to stakeholders is essential in order for listed firms to raise capital. Hutton (2004) attests that corporate voluntary disclosure continues to be important because information is vital for the efficient functioning of capital markets and in building investor confidence.

The extent of voluntary disclosure has been an area of interest to accounting researchers over the two past decades. Healy \& Palepu (2001, p.407) believe that "financial accounting and disclosure will continue to be a rich field of empirical inquiry". Beattie (2005) attributes changes in the business environment to the burgeoning research into voluntary disclosure. The 1997 crisis and the rampant corporate collapses provide examples of significant environmental change that have shaped corporate reporting and the governance landscape towards one characterized by greater transparency and accountability.

This study investigates the determinants of voluntary disclosure practices of listed firms in Malaysia. The research questions are: (i) what is the extent of voluntary disclosures in the annual reports of Malaysian listed firms in the 1996, 2001 and 2006 financial years?; and (ii) are there statistically significant associations between the strength of corporate governance and ownership structure and the extent of voluntary disclosure of these firms? As Barako (2004) finds no great variation in the pattern of disclosure practices between consecutive years, this study evaluates the trend in disclosure practices at three key points in time: 1996, 2001 and 2006. The period 1996-2006 encompasses the Asian financial crisis (1996), 
governance reforms subsequent to the Asian financial crisis (2001) and regulatory and governance changes following the corporate collapses in Malaysia and globally (2006). Changes in the economic, financial and regulatory environment in each of the 1996, 2001 and 2006 years are expected to result in more extensive changes in disclosure practices. Further, it is not unreasonable to expect that changes in the disclosure incentives and practices will come about as a consequence of these environmental changes.

The study is motivated by transformation of the Malaysian corporate reporting and governance environment over the 1996-2006 period. These environmental changes provide a unique institutional setting for this research. Over the past decade, numerous initiatives have been implemented by Malaysian regulatory authorities to enhance corporate transparency and accountability. It is an open question as to what extent the subsequent action of reforms influence the variation in the level of information voluntarily disclosed by Malaysian listed firms. Another feature that motivates this study is the concentrated ownership structures of Malaysian corporations. The World Bank (1999) reports that, on average, $60 \%$ of the total equity in Malaysian listed firms is held by the top five shareholders. The impact of ownership structure is of particular significance as Malaysia endeavours to become a major international capital market (Shimomoto, 1999). In a capital market setting, the ability of firms to raise capital for investment and growth at competitive rates depends on firm's communication strategies with investors. Disclosure serves as a strategic communication tool for firms to convey essential information to investors in emerging markets such as Malaysia. The higher transparency expectations pose an important challenge to Malaysian listed firms in providing credible disclosure. Accordingly, the study of information disclosure of a voluntary nature within the Malaysian context is essential and timely. 
Based on a matched-sample of 100 Malaysian listed firms in each of the 1996, 2001 and 2006 years, we find that there is an increase in the extent of Malaysian listed firm's voluntary disclosures in annual reports from 1996 to 2006. Overall, the result shows that firms with enhanced corporate governance structure and concentrated ownership structure are more likely to voluntarily disclose information. The findings provide evidence that regulatory changes in the Malaysian context served to increase the extent of voluntary disclosures of listed firms possibly owing to increased strength in governance reforms.

This study provides a segmented longitudinal examination of voluntary disclosure patterns and its association with corporate governance structure and ownership structure subsequent to the implementation of regulatory initiatives in Malaysia. A unique corporate governance score comprising thirteen governance attributes is used to assess the strength of the corporate governance structure. The findings of this study are particularly relevant to regulators and policy-makers given the important roles that corporate governance structure and ownership structure play in mitigating agency problems.

The remainder of the study is structured as follows: Section 2 illustrates the Malaysian corporate reporting and governance environment; Section 3 discusses relevant prior literature and the hypotheses; Section 4 describes the data and methodology; Section 5 presents the study findings and robustness testing; and Section 6 concludes the study with final comments, limitations and suggestions for future research.

\subsection{Corporate reporting and governance in Malaysia}

Prior to 1996, the Malaysian corporate reporting was self-regulated and intermittently overseen by accounting professional bodies, such as the Malaysian Institute of Accountants 
and Malaysian Association of Certified Public Accountants. The regulatory regime that governed the financial reporting was merit-based where the firms disclosed the information as required and were accountable to regulators (Securities Commission, 1999). Since the disclosure was arguably not user-oriented, the limited information flow under this regime effectively lowered market incentives for greater disclosure (Cheng and Courtenay, 2006).

The Malaysian accounting landscape radically changed with the establishment of an independent, statutorily incorporated, accounting standard-setting body in 1997. This occurred at a time when Malaysian listed firms were subject to financial distress during the 1997 East Asian financial crisis. Under the new financial reporting regime, the Malaysian Accounting Standards Board (MASB) and the Financial Reporting Foundation (FRF) were established under the Financial Reporting Act 1997 (FRA). Concomitantly, the Malaysian Securities Commission (MSC) shifted the regulatory regime to a disclosure-based regime (DBR) with greater expectations of firms to disclose information and to demonstrate greater accountability. The DBR entails the making of investment decisions by each prospective investor based upon the provision of sufficient and accurate information in publicly available documents. There is a greater market incentive for enhanced disclosure under the DBR (Cheng and Courtenay, 2006).

Subsequent to the 1997 Asian currency crisis, there was a concerted effort to raise the standard of corporate governance practices in Malaysia. In 1998, a High Level Finance Committee on Corporate Governance (HLCG) was commissioned by the MSC to deal with the weakness in the corporate governance framework in Malaysia. This led to the issuance of the Malaysian Code of Corporate Governance (MCCG) which was eventually introduced to the Malaysian corporate sectors in 2001. The MCCG aims to encourage disclosure by 
providing investors with timely and relevant information to facilitate investment decision making (Abdul Rahman, 2006).

A taskforce on Corporate Disclosure Best Practice was formed in October 2002 as part of BMLR to provide guidance on governance practices. They issued guidelines entitled Best Practices in Corporate Disclosure in August 2004. The guidance identifies practices to guide companies in complying with their disclosure obligations under the BMLR. Although these best practices are voluntary, listed firms are encouraged to incorporate these guidelines into their own disclosure practices with the purpose of assisting companies to move beyond minimum disclosure practices (Bursa Malaysia, 2004).

From this overview of the regulation of corporate reporting and governance in Malaysia, it is apparent that these developments have had a substantial impact on a firm's disclosure policy. The challenges for corporations and regulators are to continue to enhance the levels of transparency, governance and accountability in the Malaysian capital market.

\subsection{Literature review and hypotheses development}

Agency theory is most commonly used framework in the accounting literature to analyse voluntary disclosure choice. The theory models the relationship between the principal and the agent as identified by Jensen and Meckling (1976). The separation of the ownership and control gives rise to agency problems because of goals conflict between shareholders and managers (Eisenhardt, 1989). In the context of the firm, a major issue arising from such separation is the extent of information asymmetry between managers and shareholders. The agency theory approach argues that a firm's choice to disclose information is a function of managerial discretion to better solve the problem of information asymmetry. Voluntary 
corporate disclosure is mainly driven by rational managers' self-interest and their attempts to protect and enhance their reputation and remuneration. To the extent that voluntary disclosure is beneficial, managers need to apply their discretion in disclosing information to stakeholders, thereby reducing the costs of the agency relationship (Healy and Palepu, 2001).

Effective corporate governance offers crucial monitoring mechanisms to co-align managerial behaviour with owner preferences or to monitor the actions of the managers (Eisenhardt, 1989). Shleifer and Vishny (1997) and Core (2001) highlight that a firm's governance structure can influence the nature of its disclosure policy in the sense that a well-designed governance structure can help ensure an optimal firm's disclosure policy. Prior empirical studies have examined the association between corporate disclosure and specific governance attributes such as board independence, role duality, audit committee; but these studies produce inconclusive evidence. Recently, the use of an index-based corporate governance measure and its relation to corporate disclosure has started to gain researchers' attention in recent years (Beekes and Brown, 2006; O’Sullivan, Percy, and Stewart, 2008; Taylor, Tower, and Neilson, 2010). According to Gompers, Ishii, and Metrick (2003), such a direct proxy measure of corporate governance is more effective in capturing the strength of a firm's governance structure. Byard, Li, and Weintrop (2006) and Beekes and Brown (2006) document better-governed firms make more informative disclosure in U.S. and Australian firms respectively. Similarly, Taylor, Tower, and Neilson (2010) document that the financial risk management disclosure patterns are significantly and positively associated with the strength of corporate governance structure. However, the primacy of corporate governance structure as an important determinant of a firm's transparent policy is queried in O'Sullivan, Percy, and Stewart (2008). They document that Australian firms disclosing forward-looking information typically experience a higher standard of corporate governance than non- 
disclosing firms in year 2000, but not in the 2002 year. In spite of the enhanced corporate governance structure in 2002 , it does not lead to more extensive disclosures of forwardlooking information.

Essentially, the adoption of the principles of corporate governance ensures management will act in the best interest of shareholders and investors and contribute to a reduction in information asymmetry (Eisenhardt, 1989). Agency theory predicts that effective corporate governance can strengthen the monitoring and control of management, thereby reducing opportunistic behaviour and information asymmetry (Fama and Jensen, 1983). Thus, it is reasonable to assume that effective corporate governance will have a positive impact on the extent of voluntary disclosures. Consistent with agency theory, this study hypothesizes:

H1: The strength of a firm's corporate governance structure is positively associated with the extent of voluntary disclosure.

Ownership structure is an important aspect of corporate governance particularly in determining the nature of the agency problem. Due to the separation of ownership and control, agency theory suggests that there is a high likelihood of agency conflict (Jensen and Meckling, 1976) with the potential for conflict to be greater when shares are widely held than when shares are tightly controlled (Fama and Jensen, 1983). The degree of separation between ownership and management determines the level of monitoring (Thomsen and Pedersen, 2000) and thereby, the extent of voluntary disclosure. Shleifer and Vishny (1997) argue that large (outside) ownership can help reduce agency conflicts due to their dominant power and incentive to prevent expropriation by insiders. In this regard, the dominant shareholders play a monitoring role and can be expected to put more pressure on management to disclose additional information. 
Empirically, Birt et al. (2006) find a positive association between ownership concentration and voluntary segment disclosure of Australian listed firms. They argue that when ownership is concentrated in the hands of large shareholders, they have the ability to mitigate agency problems by influencing information disclosure. Consistent with this view, Ho and Tower (2010) report that firm's with concentrated ownership structure have greater incentives to provide more information. They contend that large (outside) shareholders act as guardian to minority shareholders in influencing firm's disclosure choice. As such, greater information is disclosed in annual reports on a voluntary basis. Similarly, Jiang, Habib, and $\mathrm{Hu}$ (2011) acknowledge the importance of corporate disclosures under concentrated ownership structures in reducing information asymmetry in New Zealand. Consequently, the hypothesis to be tested is:

H2: The higher the proportion of shares held by the top 5 shareholders, the greater will be the extent of voluntary disclosure.

To test $\mathrm{H} 1$ and $\mathrm{H} 2$, this study includes firm-specific non-governance characteristics as control variables (firm size, leverage and industry types) in order to minimise cross-sectional variation. These control variables are reported in extant literature as being associated with the extent of voluntary disclosure. Firm size has been identified as an important predictor of corporate reporting behaviour. Due to high agency costs, large firms have the incentive to disclose more information in their annual reports to enhance reputation, reduce public scrutiny and to deter government intervention. A large volume of empirical research documents a positive association between firm size and the extent of disclosure (Akhtaruddin and Haron, 2010; Al-Shammari and Al-Sultan, 2010; Arcay and Vázquez, 2005; Botosan, 1997; Naser, Al-Khatib, and Karbhari, 2002). From the perspective of agency theory, Jensen 
and Meckling (1979) argue that high monitoring costs would be incurred by firms that are highly leveraged because there is more wealth to transfer from bondholders to shareholders. Management may voluntarily disclose more information in annual reports for monitoring purposes. Wallace, Naser, and Mora (1994) suggest that disclosure level is likely to vary based on industry, reflecting unique characteristics. Cooke (1989) draws attention to the likelihood that leading firms operating in a particular industry could have a bandwagon effect on the level of disclosure adopted by other firms within the same industry.

\subsection{Research Design}

\subsection{Sample selection}

The sample is drawn from firms listed on the BMSE in 1996, 2001 and 2006. The following criteria is used in selecting sample firms: (i) the availability of annual reports of firms for all the three years; (ii) firms selected in 1996 must remain listed on the stock exchange in the other two years; and (iii) all banks, unit trust, insurance and finance companies are excluded from the study due to different regulatory and reporting requirements. The remaining firms are then subject to stratified random selection from five industry groups namely trading and services; construction; industrial products; plantation; and consumer products. A total of 100 sample firms are randomly selected in 1996 , which represents $31.8 \%$ of the population. These firms selected are chosen as the sample firms for the other two periods. The matched sample research approach, as recommended by Ghazali and Weetman (2006), is then used to capture the effect of changes in corporate governance regulations on the extent of voluntary disclosure. The annual reports of sample firms are retrieved from the BMSE.

\subsection{Dependent variable -voluntary disclosure index}


This study uses a self-constructed disclosure index to gauge the extent of voluntary disclosure. An extensive review of prior studies is undertaken to check for common determinants of voluntary disclosure especially those attributes applicable to developing countries. Drawing on prior disclosure studies in developing countries (eg. Ghazali and Weetman, 2006; Barako, Hancock, and Izan, 2006; Alsaeed, 2005; Gul and Leung, 2004), a preliminary disclosure checklist consisting of 151 voluntary disclosure items is derived. This preliminary checklist is then thoroughly screened by two Malaysian Chartered Accountants to verify the relevance of each item to Malaysian reporting environment and to eliminate any reporting items that are mandatory in nature. The process results in the final list of 85 items to capture Malaysian corporate voluntary disclosure practices. These 85 items are categorised into: (i) corporate and strategic information; (ii) financial and capital market data; (iii) directors and senior management information; (iv) forward-looking information; and (v) corporate social responsibility. The checklist, as shown in Appendix 1, forms the basis of measuring the extent of voluntary disclosure.

Adopting Meek, Roberts, and Gray (1995) approach, this study does not weight any of the items comprising the voluntary disclosure index. Each item is scored as 1 if disclosed and 0 if it is not, subject to the applicability of the item concerned. Weighting of items is not used because the focus of this study is not directed at a particular user group. Moreover, prior research has shown that unweighted and weighted approaches produce very similar results when there are a large number of items included (Beattie, McInnes, and Fearnley, 2004; Barako, Hancock, and Izan, 2006). Voluntary disclosure index score (VDIS) is calculated for each firm in each period, expressed as follows:

$$
\mathrm{VDIS}_{\mathrm{jt}}=\frac{\sum_{t=1}^{n_{j}} X_{j t}}{n_{j t}}
$$


where VDIS $\mathrm{j}_{\mathrm{jt}}$ is the voluntary disclosure index score for firm $\mathrm{j}$ year $\mathrm{t} ; \mathrm{n}_{\mathrm{j}}$ is the number of items applicable to $\mathrm{j}^{\text {th }}$ firm; $n_{j t}$ is the total possible maximum number of items (85); $\mathrm{X}_{\mathrm{jt}}$ is voluntary disclosure item where a value of 1 is assigned if the firm discloses information about this item; and 0 if otherwise.

\subsection{Explanatory variables}

This study captures the strength of corporate governance by developing a score comprising thirteen governance items. The MCCG and Chapter 15 of the BMLR on corporate governance constitute authoritative and objective sources used for selection of corporate governance attributes. Past governance literature was used as a basis for selection of individual governance items. The thirteen governance attributes selected can be broadly classified into role duality, board composition, board sub-committees (audit, remuneration, nomination) structures, board policy and internal control systems. These attributes are used to create a composite proxy measure to capture the strength of a firm's corporate governance structure (see Appendix 2). Each of the corporate governance attributes is measured as a dichotomous variable. A value of 1 is assigned for each attribute that is presumed to reinforce the voluntary disclosure practice of a firm, and 0 otherwise. A firm receives a score ranging from 0 to 13 depending on the number of attributes satisfied. Each firm in each period has the 'opportunity' to incorporate any or all these attributes. Given this premise, the corporate governance score (CGS) are not adjusted as 'not-applicable' items. This approach is consistent with Taylor, Tower, and Neilson (2010). Firms with a low CGS are presumed to have weaker governance structure, leading to a reduced extent of voluntary disclosure. A higher score is believed to signal a stronger governance structure, leading to a greater extent of voluntary disclosure. The CGS, measured as a percentage, is treated as a continuous variable in the statistical analysis. 
BMLR requires Malaysian listed companies to provide information on the proportion of shares owned by dominant shareholders in annual reports. Corporate ownership in Malaysia is characterized by a high level of concentration of equity shareholdings. Consistent with the World Bank (2005), this study measures ownership concentration, a proxy measure of ownership structure, as the ratio of total shares owned by top five shareholders to total number of outstanding shares. Appendix $\mathrm{D}$ summarises the operationalisation and measurement of the independent and control variables.

\subsection{Model development}

A linear multiple regression model is constructed and performed to investigate the explanatory power of the predictor variables. The model is used to test the cross-sectional (within each period) associations between the dependent variable of voluntary disclosure, the independent variables of corporate governance and ownership concentration, and the control variables. The following model is estimated:

$$
\begin{aligned}
\mathrm{VDIS}_{\mathrm{jt}} & =\beta_{0}+\beta_{1} \mathrm{CGS}_{\mathrm{jt}}+\beta_{2} \mathrm{OCON}_{\mathrm{jt}}+\beta_{3} \mathrm{FSIZE}_{\mathrm{jt}}+\beta_{4} \mathrm{LEV}_{\mathrm{jt}}+\beta_{5} \mathrm{IND} 1_{\mathrm{jt}}+\beta_{6} \mathrm{IND} 2_{\mathrm{jt}} \\
& +\beta_{7} \mathrm{IND}_{\mathrm{jt}}+\beta_{8} \mathrm{IND}_{\mathrm{jt}}+\beta_{9} \mathrm{IND}_{\mathrm{jt}}+\varepsilon_{\mathrm{jt}}
\end{aligned}
$$

where subscript ${ }_{\mathrm{jt}}$ refers as firm $j$ in year $t$; VDIS $\mathrm{V}_{\mathrm{jt}}=$ voluntary disclosure index; $\mathrm{CGS}_{\mathrm{jt}}=$ corporate governance score being the composite measurement of thirteen corporate governance attributes; $\mathrm{OCON}_{\mathrm{jt}}=$ ownership concentration measured as the ratio of total shares held by top five shareholders to total number of shares issued; FSIZE $_{\mathrm{jt}}=$ firm size measured as natural log of total assets; $\mathrm{LEV}_{\mathrm{jt}}=$ leverage as ratio of debt to equity; IND $1_{\mathrm{jt}}$ $\mathrm{IND}_{\mathrm{jt}}=1$ if the company is in the consumer product sector, industrial product sector, construction and property sector, trading and services sector and plantation sector respectively; 0 if otherwise; $\beta_{0}=$ intercept; $\beta_{1}-\beta_{9}=$ estimated coefficient for each item; $\varepsilon_{\mathrm{jt}}=$ error term.

\subsection{Empirical results}

\subsection{Descriptive statistics}


The descriptive results of VDIS and five sub-categories information are provided as Table 1. There is a wide range in VDIS throughout the study period. In 1996, the lowest VDIS is $1.2 \%$ and the highest VDIS is $54.9 \%$ with a mean of $22.9 \%$. In 2001, the VDIS ranges from 5.9\% to $71.9 \%$ with a mean of $30.4 \%$. The VDIS ranges from $6.5 \%$ to $80.5 \%$ with a mean of $34.1 \%$ in 2006. There is an increase in the extent of voluntary disclosure in Malaysian listed firms from 1996 to 2006. The extent of voluntary disclosure is relatively high as compared to that in other developing countries. For instance, typical disclosures exhibited in other developing countries are: $28.9 \%$ in Singapore (Cheng and Courtenay, 2006); 24.2\% in Vietnam (Tower, Anh-Vu, and Scully, 2011); 19.0\% in Kuwait (Al-Shammari and Al-Sultan, 2010). The extent of disclosures for each sub-category of information increases from 1996 to 2006. There is a marked increase in the disclosure of information relating to directors and senior management from $15.1 \%$ in 1996 to $50.8 \%$ in 2006 . All the other categories of information demonstrate a moderate increase over the entire observation period viz. corporate and strategy information (34.8\% in 1996 to $44.3 \%$ in 2006); financial and capital market data information (25.0\% to $33.9 \%)$; forward-looking information (23.0\% to $31.2 \%)$; and corporate social responsibility information $(10.0 \%$ to $23.8 \%)$. The non-parametric KolmogorovSmirnow normality test (K-S Lilliefors) reported in Table 1 indicates that VDIS is approximately normally distributed.

Table 2 reports the paired t-test for mean VDIS over the observation periods. The analysis shows that the increase in mean VDIS for sample firms between 1996-2001, 2001-2006 and 1996-2006 is statistically significant at the 1\% level. The largest increase occurs between 1996 and 2001 (32.2\%) while the increase is moderate between 2001 and 2006 (12.3\%). Over the eleven-year study period, the increase in average voluntary disclosure between 1996 and 
2006 is $48.5 \%$. The results show that there is a significant increase in the extent of voluntary disclosure of Malaysian listed firms from 1996 to 2006.

Table 3 provides descriptive statistics for corporate governance and ownership concentration predictor variables in each year. Sample firms exhibit a weak corporate governance structure in 1996 (pre-financial crisis) with a mean CGS of 23.4\%. Governance structure is enhanced over time with an increase in mean CGS of $48.7 \%$ in 2001 and a further increase to $67.8 \%$ in 2006. Sample firms have a persistently high ownership concentration in the hands of top five shareholders over the observation periods. The mean OCON in 1996 is $61.9 \%$ although it declines slightly to $58.5 \%$ in 2006 .

The Pearson correlation coefficients for the continuous explanatory variables as well as the dependent variable in each period are reported as Table 4. The firms' strength of corporate governance structure is not correlated with the extent of voluntary disclosure in 1996. There is a significant correlation between VDIS and CGS in 2001 and 2006, while similar correlation findings are found between VDIS and OCON in all years under study. The directionality of these correlations is consistent with that hypothesised. The correlation coefficients between the continuous explanatory variables are all below 0.4. Thus, the multicollinearity in this study is considered non-problematic.

\subsection{Multivariate results}

The results of the multivariate test of the hypotheses developed are presented in Table 5. The explanatory power of the cross-sectional regression model; as indicated by the values of adjusted R-squared of $41.6 \%$ in $1996,48.1 \%$ in 2001 and $51.7 \%$ in 2006; compares favourably with prior disclosure studies in other developing countries such as Barako, 
Hancock, and Izan (2006) [53.0\%]; Eng and Mak (2003) [20.6\%]; Ghazali and Weetman (2006) [36.1\%]; Haniffa and Cooke (2002) [47.9\%]; Ho and Wong (2001) [31.4\%]; and Owusu-Ansah (1998) [52.0\%]. The model in this study is highly significant $(\mathrm{p}<0.01$ ), indicating that the model explains a substantial percentage of the variations in the level of corporate voluntary disclosure.

There is a positive and statistically highly significant association between voluntary disclosures and corporate governance structure in $2001(\mathrm{p}<0.01)$ and $2006(\mathrm{p}<0.01)$. The results support the positive association as hypothesized. Our results could potentially relate to the implementation of the MCCG in 2001 where one of its tenets is to enhance corporate transparency and accountability. The enhanced corporate governance structure and disclosure-based regime implemented post currency-crisis may have had an influence in managerial disclosure choice. The results suggest that better governed firms make greater voluntary disclosure.

Table 5 reveals that ownership concentration is positively and statistically significantly associated with voluntary disclosure in all the three years under study, supporting $H 2$. This finding is consistent with the findings of Birt et al. (2006) and Jiang, Habib, and $\mathrm{Hu}$ (2011) who report that a concentrated ownership structure can have a positive influence on managements' disclosure decisions. The positive association between ownership concentration and voluntary disclosure supports the notion that concentrated ownership structure implies stronger monitoring capacity by dominant shareholders thereby influencing management to disclose voluntary information more extensively. The positive relationship concurs with the findings of Shleifer and Vishny (1997) although it is inconsistent with the agency theoretical stance. A possible explanation for this is that dominant shareholders' 
control is stronger in providing effective monitoring in Malaysia. The substantial shareholders comprising blockholders, government agencies, banks, insurance companies, pension funds etc. help to create strong incentives to monitor corporate disclosure practices to reduce information asymmetry.

With regard to the control variables, firm size is consistently positively and statistically significantly (at the $1 \%$ levels) associated with the extent of voluntary disclosure in all years. These results confirm that the firm size is a very important attribute associated with the extent of voluntary disclosures in annual reports. Reasons for this association may relate to public scrutiny, expanded resources and the need to suppress high agency cost typical of large firms. Leverage lacks statistical significance in all years, suggesting that a company's gearing status has no bearing on the extent of information voluntarily disclosed. There appears to be no evidence that the extent of voluntary disclosure is industry-related. The coefficients for the rest of the industry-type dummies are not significant except in 2006 where trading and service sector tends to disclose less voluntary information disclosure. Relative secrecy on the part of companies in this sector may reflect a fear incurring proprietary costs through disclosure to competitors.

\subsection{Robustness tests}

Additional tests are conducted to check the robustness of the findings. To supplement the earlier findings, data is transformed and run using rank regression and normal scores approaches (Camfferman and Cooke, 2002; Cooke, 1998). The results of the additional rank regression and normal scores analysis (not shown for brevity) highlight that corporate governance structure is positively and significantly associated with voluntary disclosure in 2001 and 2006; and ownership structure is a significant positive predictor of the extent of 
voluntary disclosure in all three observation periods across the two approaches. Importantly, the additional tests highlight that the variables identified as significant predictors of the extent of voluntary disclosure are the same as the main statistical test on untransformed data. Overall, the results are robust across different approaches. This multiple-tiered analysis provides comfort to the validity of the main statistical findings.

The multiple regression model used in the study implicitly assumes the exogenous determination of both corporate governance and ownership structure variables. However, a concern arises from the possibility of the endogenous determination of corporate governance and ownership structure. The model may suffer from causality as well as unobserved heterogeneity (Larcker and Rusticus, 2010) where the explanatory corporate governance and ownership structure variables may be endogenous and correlated with the residuals in the regression model. Should endogeneity adversely bias the OLS models used in this study, it would be difficult to interpret the association between corporate governance and ownership structure and voluntary disclosure. The study takes advantage of the longitudinal design of this study and employs panel data OLS regression with firm fixed-effects to eliminate endogeneity, as suggested by Himmelberg, Hubbard, and Palia (1999). The observation from the pooled results (not shown for brevit) shows that the model is significant with an F-value of 33.15 and an adjusted $\mathrm{R}^{2}$ of $53.4 \%$. The result indicates that voluntary disclosure by Malaysian companies has increased over the eleven-year period and is statistically significant. Corporate governance structure, ownership structure and firms size are positively and significantly associated with voluntary disclosure practices.

Another method to address potential endogeneity is to examine the association between changes in the levels of governance (Karamanou and Vafeas, 2005). This approach is 
appropriate since there is less likely to be a corresponding change in any potential omitted variable that is correlated with both the dependent and independent variables. The setback of this approach is that the change in independent variables may be relatively minor between periods compared to the change in dependent variable. Nonetheless, the change multiple regression is conducted and the results (not shown for brevity) indicate that there is no significant association between the change in voluntary disclosure and the change in corporate governance and ownership structure. This further analysis lessens any possible concern of the endogeneity in the determination of corporate governance and ownership structure.

\subsection{Implications and conclusions}

The purpose of this study is to investigate the extent of voluntarily disclosed information within the annual reports of Malaysian listed firms from 1996 to 2006. The extent of Malaysian listed firm's voluntary disclosures in annual reports increases from 1996 to 2006. The result suggests that firms are disclosing greater information of a discretionary nature in the post currency crisis period compared to pre-crisis period. There is a greater increase in voluntary disclosures between 1996 and 2001 although moderate increase between 2001 and 2006. The results suggest the regulatory efforts have influenced corporate communication of information on a voluntary basis in annual reports.

The regression results show that corporate governance structure is a significant predictor in 2001 and 2006. The implementation of MCCG provides the catalyst for a concerted effort to enhance corporate transparency and accountability. Our results also lend support to prior studies of the use of a corporate governance index as a measure of the effectiveness of corporate governance structure. 
The positive association between ownership concentration and voluntary disclosure in all years highlight that Malaysian firms with large shareholder concentration promote more extensive disclosures. Specifically, the Malaysian regulators may encourage equity participation by varying investors groups who have the potential to strengthen corporate transparency. This would ensure firms dominated by large shareholders have better incentives and resources to monitor management decisions and reduce agency costs, as posited by Shleifer and Vishny (1997). This is of particularly importance if Malaysian firms are to penetrate international capital markets as a source to raise funds to finance economic activities.

Overall, the empirical results of this study contribute to the extant literature by providing valuable insights regarding the extent of voluntary information disclosure among listed firms of an emerging economy - Malaysia. Although the extent of voluntary disclosure has increased over the 11-year period, the Malaysian regulators should continue to strengthen the regulatory framework regarding the level of listed firms' disclosure practices. These results may assist other East Asian countries which largely have the same governance architecture as Malaysia to improve market transparency through greater disclosures.

This study is not without limitations. Although the study documents the expected association between the explanatory variables and dependent variable, it does not consider the causal relationship. Using the multiple regression model, this study is not possible, nor is it intended, to ascertain whether independent variables directly influenced the dependent variable. This study may suffer from survivorship biasness as it includes same firms in the sample over the three periods. It is suggested that in the future, research should explore the 
use of other statistical analysis e.g. Structural Equation Modelling to examine the causal relationship. Future research could extend the study by undertaking a comparative study with companies listed on other stock exchanges within the East Asian countries. 


\section{References}

Abdul Rahman, R. (2006). Effective Corporate Governance, Universiti Publication Centre, Kuala Lumpur.

Akhtaruddin, M. and Haron, H. (2010) 'Board ownership, audit committees' effectiveness and corporate voluntary disclosure’, Asian Review of Accounting, Vol. 18 No. 3, pp. 245-259.

Al-Shammari, B. and Al-Sultan, W. (2010) 'Corporate governance and voluntary disclosure in Kuwait', International Journal of Disclosure and Governance, Vol. 7 No. 3, pp. 262-280.

Alsaeed, K. (2005) 'The association between firm-specific characteristics and disclosure: The case of Saudi Arabia', The Journal of American Academy of Business, Vol. 7 No. 1, pp. 310-321.

Arcay, M.R.B. and Vázquez, M.F.M. (2005) 'Corporate characteristics, governance rules and the extent of voluntary disclosure in Spain', Advances in Accounting, Vol. 21, pp. 299-331.

Armitage, S. and Marston , C.L. (2008) 'Corporate disclosure, cost of capital and reputation: evidence from finance directors', The British Accounting Review, Vol. 40 No. 4, pp. 314-336.

Barako, D.G. (2004) Voluntary corporate disclosure by Kenyan companies: A longitudinal exploratory study. Unpublished $\mathrm{PhD}$ thesis, The University of Western Australia, Perth, Australia.

Barako, D.G., Hancock, P. and Izan, H.Y. (2006) 'Factors influencing voluntary corporate disclosure by Kenyan companies', Corporate Governance: An International Review, Vol. 14 No. 2, pp. 107-125.

Beattie, V. (2005) 'Moving the financial accounting research front forward: the UK contribution', The British Accounting Review, Vol. 37 No. 1, pp. 85-114.

Beattie, V., McInnes, W. and Fearnley, S. (2004) 'A methodology for analyzing and evaluating narratives in annual reports: a comprehensive descriptive profile and metrics for disclosure quality attributes', Accounting Forum, Vol. 28 No. 3, pp. 205-236.

Beekes, W. and Brown, P. (2006) 'Do better-governed Australian firms make more informative disclosures?', Journal of Business Finance \& Accounting, Vol. 33 No. 3, pp. 422-450.

Birt, J.L., Bilson, C.M., Smith, T. and Whaley, R.E. (2006) 'Ownership, competition and financial disclosure', Australian Journal of Management, Vol. 31 No. 2, pp. 235-263.

Botosan, C.A. (1997) 'Disclosure level and the cost of capital', The Accounting Review, Vol. 72 July, pp. 323-349.

Bursa Malaysia (2004) Best Practices in Corporate Disclosure. Bursa Malaysia, Kuala Lumpur. 
Byard, D., Li, Y. and Weintrop, J. (2006) 'Corporate governance and the quality of financial analyst information', Journal of Accounting and Public Policy, Vol. 25 No. 5, pp. 609-625.

Camfferman, K. and Cooke, T.E. (2002) 'An analysis of disclosure in the annual reports of U.K. and Dutch companies', Journal of International Accounting Research, Vol. 1 No. 3, pp. 3-30.

Chau, G.K. and Gray, S.J. (2002) 'Ownership structure and corporate voluntary disclosure in Hong Kong and Singapore', The International Journal of Accounting, Vol. 37 No. 2, pp. 247265.

Cheng, E.C.M. and Courtenay, S.M. (2006) 'Board composition, regulatory regime and voluntary disclosure', The International Journal of Accounting, Vol. 41 No. 3, pp. 262-289.

Cooke, T.E. (1989) 'Disclosure in the corporate annual report of Swedish companies', Accounting and Business Research, Vol. 19 No. 74, pp. 113-122.

Cooke, T.E. (1998) 'Regression analysis in accounting disclosure studies', Accounting and Business Research, Vol. 28 No. 3, pp. 209-224.

Core, J.E. (2001) 'A review of the empirical disclosure literature: discussion', Journal of Accounting and Economics, Vol. 31 No. 1-3, pp. 441-456.

Eisenhardt, K.M. (1989) 'Agency theory: an assessment and review', Academy of Management, Vol. 14 No. 1, pp. 57-74.

Eng, L.L. and Mak, Y.T. (2003) 'Corporate governance and voluntary disclosure', Journal of Accounting and Public Policy, Vol. 22 No.4, pp. 325-345.

Fama, E.F. and Jensen, M.C. (1983) 'Separation of ownership and control', Journal of Law and Economic, Vol. 26 No. 2, pp. 301-325.

Ghazali, N. and Weetman, P. (2006) 'Perpetuating traditional influences: voluntary disclosure in Malaysia following the economic crisis', Journal of International Accounting, Auditing \& Taxation, Vol. 15 No. 2, pp. 226-248.

Gompers, P.A., Ishii, J. and Metrick, A. (2003) 'Corporate governance and equity prices', The Quarterly Journal of Economics, Vol. 118 No. 1, pp. 107-156.

Gul, F.A. and Leung, S. (2004) 'Board leadership, outside directors' expertise and voluntary corporate disclosure', Journal of Accounting \& Public Policy, Vol. 23 No. 5, pp. 351-379.

Ho, P.L. and Tower, G. (2011) 'Ownership structure and voluntary disclosures in corporate annual reports of Malaysian listed firms', Corporate Ownership and Control, Vol. 8 No. 2, pp. 296-313.

Haniffa, R.M. and Cooke, T.E. (2002) 'Culture, corporate governance and disclosure in Malaysian corporations', Abacus, Vol. 38 No. 3, pp. 317-349. 
Healy, P.M. and Palepu, K.G. (2001) 'Information asymmetry, corporate disclosure and the capital markets: A review of the empirical disclosure literature', Journal of Accounting and Economics, Vol. 31 No. 1-3, pp. 405-440.

Himmelberg, C.P., Hubbard, R.G. and Palia, D. (1999) 'Understanding the determinants of managerial ownership and the link between ownership and performance', Journal of Financial Economics, Vol. 53 No. 3, pp. 353-384.

Ho, S.M. and Wong, K.S. (2001) 'A study of the relationship between corporate governance structures and the extent of voluntary disclosure', Journal of International Accounting, Auditing \& Taxation, Vol. 10 No. 2, pp. 139-156.

Hutton, A. (2004) 'Beyond financial reporting - An integrated approach to disclosure', Journal of Applied Corporate Finance, Vol. 16 No. 4, pp. 8-16.

Jensen, M.C. and Meckling, W.H. (1976) 'Theory of the firm: Managerial behavior, agency costs and ownership structure', Journal of Financial Economics, Vol. 3 No. 4, pp. 305-360.

Jiang, H., Habib, A. and $\mathrm{Hu}, \mathrm{B}$. (2011) 'Ownership concentration, voluntary disclosures and information asymmetry in New Zealand', The British Accounting Review, Vol. 43 No. 1, pp. 3953.

Karamanou, I. \& Vafeas, N. (2005) 'The association between corporate boards, audit committees, and management earnings forecasts: An empirical analysis', Journal of Accounting Research, Vol. 43 No. 3, pp. 453-486.

Larcker, D.F., David, F. \& Rusticus, T.O. (2007) 'Endogeneity and empirical accounting research', European Accounting Review, Vol. 16 No. 1, pp. 207-215.

Malaysian Institute of Economy Research (2004). Foreign capital inflows vital for growth momentum [online]. http://www.mier.org.my. (Accessed 30 May 2006).

Meek, G.K., Roberts, C.B. and Gray, S.J. (1995) 'Factors influencing voluntary annual report disclosures by U.S., U.K. and Continental European multinational corporations', Journal of International Business Studies, Vol. 26 No. 3, pp. 555-572.

Naser, K., Al-Khatib, K. and Karbhari. Y. (2002) 'Empirical evidence on the depth of corporate information disclosure in developing countries: The case of Jordan', International Journal of Commerce \& Management, Vol. 12, No. 3-4, pp. 122-155.

O'Sullivan, M., Percy, M. and Stewart, J. (2008) 'Australian evidence on corporate governance attributes and their association with forward-looking information in the annual reports', Journal of Management and Governance, Vol. 12 No. 1, pp. 5-35. 
Owusu-Ansah, S. (1998) 'The impact of corporate attributes on the extent of mandatory disclosure and reporting by listed companies in Zimbabwe', The International Journal of Accounting, Vol. 33 No. 5, pp. 605-631.

Securities Commission (1999) Disclosure-based Regulation - What Directors Need To Know, Securities Commission, Kuala Lumpur.

Shimomoto, Y. (1999) 'The capital market in Malaysia', in Rhee, S.G. (Ed) Rising to the Challenge in Asia: A Study of Financial Market: Vol. 8 - Malaysia, Asian Development Bank, Hawaii, pp. 79-112.

Shleifer, A. and Vishny, R. (1997) 'A survey of corporate governance', The Journal of Finance, Vol. 52 No. 2, pp. 737-783.

Taylor, G., Tower, G., Van Der Zahn, M. \& Neilson, J. (2008). Corporate governance determinants on Australian resource companies' financial instrument disclosure practices. Asian Review of Accounting, 16, 56-73.

Taylor, G., Tower, G. and Neilson, J. (2010) 'Corporate communication of financial risk', Accounting and Finance, Vol. 50 No. 2, pp. 417-446.

Thomsen, S. and Pedersen, T. (2000) 'Ownership structure and economic performance in the largest European companies', Strategic Management Journal, Vol. 21 No. 6, pp. 689-705.

Tower, G., Anh-Vu, K. and Scully, G. (2011) 'Corporate communication for Vietnamese listed firms', Asian Review of Accounting, Vol. 19 No. 2, pp. 125-146.

Wallace, R.S.O., Naser, K. and A. Mora. (1994) 'The relationship between the comprehensiveness of corporate annual reports and firm characteristics in Spain', Accounting and Business Research, Vol. 25 Vol. 97, pp. 41-53.

Watts, R.L. and Zimmerman, J.L. (1990) 'Positive accounting theory: a ten-year perspective', Accounting Review, Vol. 65 No. 1, pp. 131-156.

World Bank (1999). Report on the Observance of Standards and Codes on Malaysia, http://www.worldbank.org/ifa/rosc cg malaysia.html. accessed on 12 July 2007. 
TABLE 1: Descriptive statistics for voluntary disclosure index score

\begin{tabular}{lrrrrrr}
\hline & Overall & & & & & \\
& VDIS & \multicolumn{1}{c}{ CSI } & FCMI & DSMI & FLI & CSRI \\
\hline M96 & & & & & & \\
Mean & 22.97 & 34.802 & 25.00 & 15.08 & 23.0 & 10.04 \\
Standard Deviation & 11.31 & 0.150 & 0.19 & 0.25 & 0.00 & 1.00 \\
Minimum & 1.17 & 0.000 & 0.00 & 0.14 & 0.00 & 0.70 \\
Maximum & 54.88 & 0.731 & 0.78 & 0.13 & 0.00 & 0.56 \\
Skewness & 0.48 & 0.005 & 0.00 & 0.00 & 0.01 & 0.01 \\
K-S Significance & 0.39 & 0.842 & 0.05 & 0.74 & 0.09 & 0.11 \\
2001 & & & & & & \\
Mean & 30.38 & 41.09 & 30.57 & 44.67 & 27.02 & 17.57 \\
Standard Deviation & 13.59 & 0.18 & 0.19 & 0.21 & 0.14 & 0.18 \\
Minimum & 5.88 & 0.00 & 0.00 & 0.00 & 0.00 & 0.00 \\
Maximum & 71.95 & 0.81 & 0.83 & 1.00 & 0.60 & 0.69 \\
Skewness & 0.59 & 0.00 & 0.00 & 0.00 & 0.00 & 0.01 \\
K-S Significance & 0.67 & 0.97 & 0.20 & 0.46 & 0.09 & 0.18 \\
2006 & & & & & & \\
Mean & 34.84 & 44.30 & 33.90 & 50.75 & 31.18 & 23.83 \\
Standard Deviation & 17.11 & 0.21 & 0.20 & 0.23 & 0.15 & 0.24 \\
Minimum & 6.49 & 0.000 & 0.00 & 0.25 & 0.000 & 0.00 \\
Maximum & 80.49 & 0.85 & 0.890 & 1.00 & 0.73 & 0.83 \\
Skewness & 0.52 & 0.00 & 0.01 & 0.00 & 0.02 & 0.04 \\
K-S significance & 0.21 & 0.51 & 0.12 & 0.39 & 0.05 & 0.20 \\
\hline
\end{tabular}

Legend: The table provides the descriptive statistics of the overall extent of voluntary disclosure and the five major sub-categories of voluntary disclosure. These sub-categories included CSI = corporate and strategic disclosure index; FCMI = financial and capital market data disclosure index; DSMI $=$ directors and senior management disclosure index; FLI = forward-looking disclosure index; and CSRI = corporate social responsibility disclosure index.

TABLE 2: Paired t-test of firms' overall VDIS

\begin{tabular}{llll}
\hline & $1996-2001$ & $2001-2006$ & $1996-2006$ \\
\hline Mean of paired differences & 7.403 & 3.741 & 11.144 \\
\% change VDIS (VDIS $\left.\mathrm{t}_{\mathrm{t}} \mathrm{VDIS}_{\mathrm{t}-1}\right)$ & 32.226 & 12.316 & 48.511 \\
Correlation & $0.814^{*}$ & $0.819^{*}$ & $0.748^{*}$ \\
$\mathrm{t}-\mathrm{Stat}$ & -9.371 & -4.393 & -10.049 \\
$\mathrm{P}(\mathrm{T}<=\mathrm{t})$ one-tail & 0.000 & 0.000 & 0.000 \\
\hline
\end{tabular}

Legend: The table shows the paired sample t-test results for mean VDIS performed by comparing 1996 with 2001, 2001 and 2006, and 1996 and 2006. The percentage change in mean VDIS (VDIS ${ }_{t}-$ VDIS $_{t-1}$ ) between two years is shown. The correlation between paired samples is significant at the $1 \%$ level. 
TABLE 3: Descriptive statistics of independent variables

\begin{tabular}{lcccccc}
\hline & \multicolumn{3}{c}{ CGS } & \multicolumn{3}{c}{ OCON } \\
\hline & 1996 & 2001 & 2006 & 1996 & 2001 & 2006 \\
\hline Mean & 23.390 & 48.692 & 67.769 & 61.866 & 57.538 & 58.477 \\
Median & 23.080 & 48.150 & 68.230 & 62.100 & 59.515 & 59.715 \\
Standard Deviation & 10.192 & 19.158 & 13.015 & 14.915 & 18.708 & 15.140 \\
Minimum & & & & & & \\
Maximum & 0.000 & 7.690 & 38.460 & 24.400 & 17.890 & 22.100 \\
\hline & 46.150 & 92.310 & 92.310 & 88.150 & 90.700 & 90.420 \\
\hline
\end{tabular}

Legend: The table reports the descriptive statistics of CGS and OCON for each period.

TABLE 4: Pearson Correlation Matrix

\begin{tabular}{|c|c|c|c|c|c|c|}
\hline & 1996 & VDIS & CGS & OCON & FSIZE & LEV \\
\hline VDIS & & 1 & & & & \\
\hline CGS & & 0.152 & 1 & & & \\
\hline OCON & & $0.327 *$ & -0.004 & 1 & & \\
\hline FSIZE & & $0.364 *$ & $0.254^{* * *}$ & 0.035 & 1 & \\
\hline LEV & & -0.119 & -0.125 & -0.171 & 0.108 & 1 \\
\hline \multicolumn{7}{|c|}{2001} \\
\hline VDIS & & 1 & & & & \\
\hline CGS & & $0.463 *$ & 1 & & & \\
\hline OCON & & $0.295^{*}$ & $0.276^{*}$ & 1 & & \\
\hline FSIZE & & $0.403^{*}$ & $0.267^{*}$ & 0.129 & 1 & \\
\hline LEV & & -0.016 & -0.123 & $-0.376^{*}$ & 0.149 & 1 \\
\hline \multicolumn{7}{|c|}{2006} \\
\hline VDIS & & 1 & & & & \\
\hline CGS & & $0.214 * *$ & 1 & & & \\
\hline OCON & & $0.307 *$ & 0.061 & 1 & & \\
\hline FSIZE & & $0.479^{*}$ & 0.025 & 0.031 & 1 & \\
\hline LEV & & -0.012 & -0.099 & $-0.359^{*}$ & 0.189 & 1 \\
\hline
\end{tabular}

Legend: Pearson Product-Moment Correlation Matrix 
TABLE 5: Cross- Sectional multivariate analysis of determinant of voluntary disclosure

\begin{tabular}{|c|c|c|c|c|c|c|c|c|c|c|}
\hline \multicolumn{2}{|l|}{ 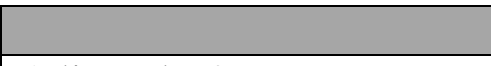 } & \multicolumn{3}{|l|}{1996} & \multicolumn{3}{|l|}{2001} & \multicolumn{3}{|l|}{2006} \\
\hline \multicolumn{2}{|l|}{ Adjusted R2 } & \multicolumn{3}{|l|}{0.416} & \multicolumn{3}{|l|}{0.481} & \multicolumn{3}{|l|}{0.517} \\
\hline \multicolumn{2}{|l|}{ Durbin Watson } & \multicolumn{3}{|l|}{2.218} & \multicolumn{3}{|l|}{2.109} & \multicolumn{3}{|l|}{2.128} \\
\hline \multicolumn{2}{|l|}{ F Statistics } & \multicolumn{3}{|l|}{9.806} & \multicolumn{3}{|l|}{12.563} & \multicolumn{3}{|l|}{14.073} \\
\hline \multicolumn{2}{|l|}{ Significance } & \multicolumn{3}{|l|}{$0.000 *$} & \multicolumn{3}{|l|}{$0.000^{*}$} & \multicolumn{3}{|l|}{$0.000 *$} \\
\hline & $\begin{array}{l}\text { Predicted } \\
\text { Sign }\end{array}$ & Coefficients & t Stat & P-value & Coefficients & t Stat & $\mathrm{P}$-value & Coefficients & t Stat & P- Value \\
\hline Intercept & & -58.018 & -5.249 & $0.000^{*}$ & -58.243 & -5.425 & $0.000 *$ & -59.361 & -7.476 & $0.000 *$ \\
\hline CGS & + & 0.072 & 0.799 & 0.213 & 0.209 & 3.719 & $0.000^{*}$ & 2.270 & 2.877 & $0.002 *$ \\
\hline OCON & - & 0.213 & 3.485 & $0.000 *$ & 0.094 & 1.532 & $0.048 * *$ & 0.261 & 2.705 & $0.003^{*}$ \\
\hline FSIZE & + & 11.228 & 6.935 & $0.000 *$ & 122.408 & 6.346 & $0.000^{*}$ & 18.860 & 8.743 & $0.000^{*}$ \\
\hline LEV & - & -5.223 & -1.091 & 0.139 & -1.601 & -0.281 & 0.389 & 1.690 & 0.314 & 0.377 \\
\hline IND1 & $+/-$ & 2.336 & 0.773 & 0.425 & 0.604 & 0.183 & 0.855 & - & - & - \\
\hline IND2 & $+/-$ & 2.683 & 0.898 & 0.399 & -0.355 & -0.103 & 0.918 & -4.580 & -1.207 & 0.230 \\
\hline IND3 & $+/-$ & 1.282 & 0.437 & 0.646 & -0.164 & -0.049 & 0.961 & -3.067 & -0.772 & 0.442 \\
\hline IND4 & $+/-$ & - & - & - & -1.753 & -0.489 & 0.626 & -11.468 & -2.687 & $0.004 *$ \\
\hline IND5 & $+/-$ & 4.844 & 1.494 & 0.141 & - & - & - & -4.992 & -1.214 & 0.228 \\
\hline
\end{tabular}

The table shows the results of the regression model which tests the association between voluntary disclosure for all sample firms over each of the three years (1996, 2001 \& 2006) against the independent and control variables. The coefficients of the excluded dummy variables are 1.000 since they act as benchmarks for the included dummies. Associations *,** and *** are statistically significant at the $1 \%, 5 \%$ and $10 \%$ levels respectively. One-tailed probabilities are used for the tests of the CGS, OCON, FSIZE and LEV variables since the associated hypotheses are directional while the two-tailed probabilities are used for the tests of the industry membership variables. 
APPENDIX 1 Voluntary Disclosure Instrument

\begin{tabular}{|c|c|}
\hline \multicolumn{2}{|r|}{ Corporate and strategic disclosure index (CSD) } \\
\hline 1 & Financial highlights -5 years and more \\
\hline 2 & Pictures of major types of product \\
\hline 3 & Discussion of company's major products / services / projects \\
\hline 4 & Information on new product development \\
\hline 5 & Discussion of industry trends (past) \\
\hline 6 & Information on acquisitions and expansion \\
\hline 7 & Statement of ways of improvement in product quality \\
\hline 8 & General statement of corporate strategy \\
\hline 9 & Organization structure / group chart \\
\hline 10 & Information relating to the general outlook of the economy \\
\hline 11 & Discussion of competitive environment \\
\hline 12 & Information on disposal and cessation \\
\hline 13 & A statement of corporate goals \\
\hline 14 & Vision and mission statement \\
\hline 15 & Description of marketing and distribution network for products/services \\
\hline 16 & Statement of ways of improvement in customer service \\
\hline 17 & Discussion of principal markets \\
\hline 18 & Actions taken during the year to achieve the corporate goal \\
\hline 19 & Brief history of the company \\
\hline 20 & Significant events calendar \\
\hline 21 & Reasons for the acquisitions \& expansion \\
\hline 22 & Impact of strategy on current and/or future results \\
\hline 23 & Discussion about major regional economic development \\
\hline 24 & Reasons for the disposal and cessation \\
\hline 25 & Description of R\&D projects \\
\hline 26 & Impact of competition on current profit \\
\hline 27 & Company's contribution to the national economy \\
\hline 28 & Information about regional political stability \\
\hline \multicolumn{2}{|r|}{ Financial and capital market data disclosure index (FCMD) } \\
\hline 29 & $\begin{array}{l}\text { Key financial ratios eg. return on assets, return on shareholders' funds, leverage, } \\
\text { liquidity }\end{array}$ \\
\hline 30 & Review of operations by divisions - operating profit \\
\hline 31 & Review of operations - productivity \\
\hline 32 & $\begin{array}{l}\text { Review of current financial results, discussion of major factors underlying } \\
\text { performance }\end{array}$ \\
\hline 33 & Effect of acquisitions \& expansion on results \\
\hline 34 & Effect of disposal \& cessation on results \\
\hline 35 & Statement concerning wealth created eg. value added statement \\
\hline
\end{tabular}




\begin{tabular}{|c|c|}
\hline 36 & Volume of shares traded (trend) \\
\hline 37 & Volume of shares traded (year-end) \\
\hline 38 & Share price information (trend) \\
\hline 39 & Share price information (year-end) \\
\hline 40 & Market capitalization (trend) \\
\hline 41 & Market capitalization (year-end) \\
\hline 42 & Analysis of distribution of shareholdings by type of shareholders \\
\hline 43 & Domestic and foreign shareholdings breakdown \\
\hline 44 & Segmental reporting on size, growth rate on product market \\
\hline 45 & Segment reporting on all lines of business production data \\
\hline 46 & Segment reporting on geographical capital expenditure \\
\hline 47 & Segment reporting on geographical production \\
\hline \multicolumn{2}{|r|}{ Directors and senior management disclosure index (DSMD) } \\
\hline 48 & Academic \& professional qualifications of directors \\
\hline 49 & Position or office held by executive directors \\
\hline 50 & Picture of senior management team \\
\hline 51 & Senior management responsibilities, experience and background \\
\hline \multicolumn{2}{|c|}{ Forward-looking disclosure index (FLD) } \\
\hline 52 & $\begin{array}{l}\text { Discussion of specific external factors affecting company's prospects (economy, } \\
\text { politics, technology) }\end{array}$ \\
\hline 53 & Discussion of company’s prospects (general) \\
\hline 54 & Discussion of likely effect of business strategy on future performance \\
\hline 55 & Discussion of future industry trend \\
\hline 56 & Discussion of future products/services research and development activities \\
\hline 57 & Planned research and development expenditure \\
\hline 58 & Planned capital expenditure \\
\hline 59 & Planned advertising and publicity expenditure \\
\hline 60 & Key financial data (quantitative) forecasts eg. sales revenues, profit, EPS \\
\hline 61 & Qualitative forecasts of sales, revenues, profits, EPS \\
\hline 62 & Forecast assumptions provided \\
\hline \multicolumn{2}{|r|}{ Corporate social responsibility disclosure index (CSRD) } \\
\hline 63 & General philanthropy \\
\hline 64 & Participation in government social campaigns \\
\hline 65 & Community programs (health and education) implemented \\
\hline 66 & Statement of company environmental policies \\
\hline 67 & Environmental protection program implemented \\
\hline 68 & Awards for environmental protection \\
\hline 69 & Support rendered for public/private action designed to protect environment \\
\hline 70 & Employee's appreciation \\
\hline 71 & Picture of employees' welfare \\
\hline
\end{tabular}




\begin{tabular}{|l|l|}
\hline 72 & Discussion of employees' welfare \\
\hline 73 & Number of employees for the last two or more years \\
\hline 74 & Breakdown of workforce by line of business distribution \\
\hline 75 & Categories of employees by level of qualifications \\
\hline 76 & Corporate policy on employee training \\
\hline 77 & Amount spent on training \\
\hline 78 & Nature of training provided \\
\hline 79 & General redundancy / retrenchment information \\
\hline 80 & Indication of employee morale e.g. turnover, strikes and absenteeism \\
\hline 81 & Information about employee workplace safety \\
\hline 82 & Standard injury, lost day, and absentee rates and number of fatalities \\
\hline 83 & Health and safety standards \\
\hline 84 & Discussion of product safety \\
\hline 85 & Statement of corporate social responsibility \\
\hline
\end{tabular}


APPENDIX 2: Corporate Governance Attributes

\begin{tabular}{|l|l|l|}
\hline CG1 & \multicolumn{1}{|c|}{ Attributes } & \multicolumn{1}{|c|}{ Scoring } \\
\hline CG2 & $\begin{array}{l}\text { Independent non-executive directors comprise at least one-third } \\
\text { of the board membership }\end{array}$ & $\begin{array}{l}\text { Yes }=1 \\
\text { No }=0 \\
\text { No }=0\end{array}$ \\
\hline CG3 & $\begin{array}{l}\text { Board has defined policy of management responsibilities of the } \\
\text { board and CEO }\end{array}$ & $\begin{array}{l}\text { Yes }=1 \\
\text { No }=0\end{array}$ \\
\hline CG4 & $\begin{array}{l}\text { Audit committee chaired by independent non-executive directors } \\
\text { No }=0\end{array}$ \\
\hline CG5 & $\begin{array}{l}\text { Audit committee comprises at least three directors, majority of } \\
\text { whom are independent }\end{array}$ & $\begin{array}{l}\text { Yes }=1 \\
\text { No }=0\end{array}$ \\
\hline CG6 & $\begin{array}{l}\text { At least two members of audit committee have accounting or } \\
\text { related financial management expertise }\end{array}$ & $\begin{array}{l}\text { Yes }=1 \\
\text { No }=0\end{array}$ \\
\hline CG7 & $\begin{array}{l}\text { Remuneration committee chaired by independent non-executive } \\
\text { director }\end{array}$ & $\begin{array}{l}\text { Yes }=1 \\
\text { No }=0\end{array}$ \\
\hline CG8 & $\begin{array}{l}\text { Remuneration committee consists wholly of non-executive } \\
\text { directors }\end{array}$ & $\begin{array}{l}\text { Yes }=1 \\
\text { No }=0\end{array}$ \\
\hline CG9 & $\begin{array}{l}\text { Structured remuneration policy in place, where remuneration to } \\
\text { directors is contingent of performance }\end{array}$ & $\begin{array}{l}\text { Yes }=1 \\
\text { No }=0\end{array}$ \\
\hline CG10 & $\begin{array}{l}\text { Disclosure requirement in the annual report of the details of } \\
\text { remuneration to each director }\end{array}$ & $\begin{array}{l}\text { Yes }=1 \\
\text { No }=0\end{array}$ \\
\hline CG11 & $\begin{array}{l}\text { Nomination committee consists exclusively of non-executive } \\
\text { directors, a majority of whom are independent }\end{array}$ & $\begin{array}{l}\text { Yes }=1 \\
\text { No }=0\end{array}$ \\
\hline CG12 & $\begin{array}{l}\text { Does nomination committee adopt a formal procedure for } \\
\text { appointments to the board? }\end{array}$ & $\begin{array}{l}\text { Yes }=1 \\
\text { No }=0\end{array}$ \\
\hline CG13 & $\begin{array}{l}\text { Maintain sound system of internal control - financial, operational, } \\
\text { investment and company assets }\end{array}$ & $\begin{array}{l}\text { Yes }=1 \\
\text { No }=0\end{array}$ \\
\hline
\end{tabular}

Source: High Level Finance Committee on Corporate Governance (2000) and Bursa Malaysia (n.d.)

Legend: Thirteen corporate governance (CG) attributes derived from the principles and best practices of the Malaysian Code of Corporate Governance. To create a composite proxy measure (denoted CGS) to capture the strength of a firm's corporate governance structure, a value of one is assigned to the corporate governance conditions outlined. A firm receives a CGS score ranging from 0 to 13 depending on the number of conditions satisfied. A CGS score is calculated for each firm and financial year of the study period. The CGS, measured as a percentage, is treated as a continuous variable. 